\title{
Firm Size and R\&D on Profitability: An Empirical Analysis on Japanese Chemical and Pharmaceutical Industry*
}

\author{
Paiboon ARCHARUNGROJ and Yasuo HOSHINO \\ (University of Tsukuba)
}

\begin{abstract}
This paper investigates the influence of corporate R\&D investment on a firm's subsequent profitability and also examines the differences in $R \& D$ efficiency among firms of different sizes. In addition, the relationship between firm size and R\&D investment is also determined. It is based on regression analysis of 170 Japanese firms in chemical and pharmaceutical industry. The results indicated that the $R \& D$ expenditure and $R \& D$ intensity are positively and significantly related to the return on assets, return on equity, gross profit margin, operating income margin and ordinary income margin. Larger firms also proved to be more efficient in their management of $R \& D$ for profits for all the above mentioned profitability variables. In addition, the findings imply a positive and significant relationship between the firm size and R\&D investment, both in terms of an absolute amount and a ratio to sales.
\end{abstract}

\section{Introduction}

There has been increasing concerns among Japanese about the stagnant economy and the instability of employment, either due to the maturity of existing markets in current industries or a delay in cultivating of new ones. Since economic growth facilitated by the introduction of foreign technology no longer offers a great promise, it is necessary for Japan to take an initiative in carrying out R\&D which will pioneer new frontiers. In the past, the success of Japanese economy has been attributed to the influence of industrial development and persistent efforts to increase technological innovation (Watanabe 1995). However, with the bursting of the bubble economy in 1992, many firms cut down on their research and development investment. Average change in the rate of R\&D expenditure for Japanese manufacturing industry reached its peak in 1985 (12.6\%), going down to $3.4 \%$ in the 1986 economic slump and recovered to $11.2 \%$ during the bubble economy in

* The authors would like to thank three anonymous referees and editor for their useful comments. How ever, any remaining errors are ours.
1989. Since then, the percentage change in Japanese $R \& D$ investment increases at a decreasing rate. By 1993, and for the first time since the survey started in 1953, the rate of change in R\&D expenditure became negative $(-1.4 \%)$. (See Fig.1) This implies that there is a change in R\&D strategy of

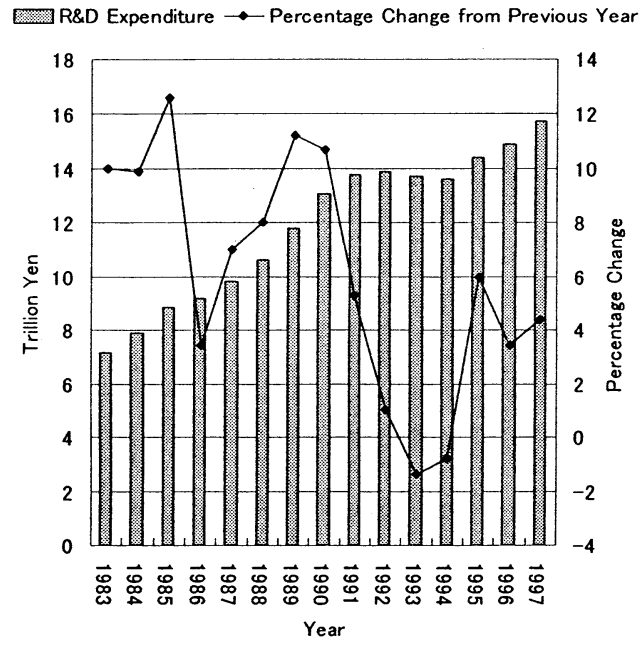

Fig 1 : Trends of Japanese R \& D

Source: Report on the Survey of Research and Development 1997. Statistics Bureau, Management and Coordination Agency of the Government of Japan.

Note: 1997 figures include software industry. 
Japanese manufacturing firms in response to the stagnated economy. Those firms seem to decrease their R\&D investment to overcome the downturn in economy and to increase their firms' overall performance. They seem to believe that innovation can be only indulged in during periods of prosperity. This is the strategy employed by many Japanese firms.

On the contrary, there is evidence supporting the hypothesis that $R \& D$ exerts an influence on subsequent performance, either explicitly or implicitly. For example, Branch (1974), using a count of the number of patents each firm received in a given year as the measurement of its R\&D activity, found a positive relationship between $R \& D$ and firm performance in his sample of 111 firms from 7 industries. Employing distributed lag techniques with pooled time-series and cross-section data, his results strongly indicated a tendency for the R\&D activity to influence both profitability and growth. Similarly, Leonard (1971) found a strong positive association between research intensity as measured by company $R \& D$ spending and growth rates of sales, assets, net income and other variables of sixteen industries performing manufacturing activities. He found that the effects of $R \& D$ upon growth begin on the average in the second year after the $R \& D$ investment and continues for at least nine years after the initial input year. Also, Gee (1981), in his observation of the performance of major sectors of U.S. industries, showed that the industries that devote a larger percent of sales to $R \& D$ are generally more profitable and competitive, whereas industries spending little on $R \& D$ are also the ones experiencing difficulties in meeting foreign competition. Other research in support of the proposition includes those of Rosenbloom and Cusumano (1987) who suggested the importance of technological capability in contributing to the global success of Japanese firms, and Odagiri (1983) who confirmed the positive effect of research on growth, though he could find evidence only among innovators, namely those in the chemical, drugs, electrical equipment, and precision equipment industries.
Thus, top management faces a difficult dilemma here, one of investing more in $R \& D$ to overcome a difficult time, and the other of decreasing $R \& D$ to cut cost for the firm to survive. This study therefore, aims to empirically analyze the relation of R\&D investment with the firm's profitability. In addition, this research extends further to investigate the relationship between firm size and $R \& D$ investment and to look for differences in $R \& D$ efficiency among firms of different sizes, using Japanese firms in the chemical and pharmaceutical industry as a sample. Chemical and pharmaceutical industry is chosen because it is an $R \& D$ intensive ${ }^{1)}$ industry in which its performance relies heavily on R\&D. A firm level study is designed in this study because the relationship between the firm size, innovation and profitability are believed to vary across industries with different technologies and market conditions. In addition, empirical analyses about $R \& D$ at the firm level are relatively scarce, especially for those in Japanese contexts (Franko 1989). The firm level study aiming at one industry is favorable also because those firms presumably possess similar characteristics, sell their products at the same market and thus should behave more similarly than firms from different industries. It is inappropriate to generalize the results of the findings on the impact of $R \& D$ on firm performances over industries that rarely conduct $R \& D$ activities. Serious problems of data, methodology or causality have also arisen where investigations have been made with all industries (Gruber, Mehta and Vernon 1967; Leonard 1971; Levin and Reiss 1981). For example, Namiki (1996), in his study of Japanese and U.S. firms, explained that the relationship between exports and $R \& D$ of Japanese manufacturing firms varies largely depending on the characteristics of the firms. He argued that Japanese firms from different industries behave differently in terms of export performance and $\mathrm{R} \& \mathrm{D}$. He suggested that by concentrating on one industry, the heterogeneous effect of Japanese manufacturing firms could have been reduced.

The purposes of this study are as follows. Firstly, it will seek to determine the effects of 
$R \& D$ spending and $R \& D$ intensity on profitability. Secondly, it will examine the differences in R\&D efficiency among firms of different sizes. Lastly, the relationship between the firm size and $R \& D$ investment is also determined. Such an analysis will enable us to answer several questions. For example, is R\&D related to the firm's profitability? If so, which are more effective in using $R \& D$ to generate profits, smaller firms or larger firms? Is it true that larger firms spend more on $R \& D$ or have higher R\&D intensity than smaller firms?

For measurement of $R \& D$, we use both the actual amount of $R \& D$ expenditures and the ratio of $R \& D$ spending to total sales ( $R \& D$ intensity). Assets of the firms are used as the proxy for size. Return on assets (ROA), return on equity (ROE), total asset turnover (TAT), gross profit margin (GPM), operating income margin (OPM) and ordinary income margin (ORM) are used to assess the firm's profitability.

This study is organized as follows. In the first section of this paper, we discuss the past literature on relationship among $R \& D$, firm size and the firm's profitability. The hypotheses to be tested are also explained. In Section II, we discuss the data used and describe our methodology. Section III presents the empirical test of the propositions using regression models and Section IV gives conclusions.

\section{Hypotheses}

Until the early 1960 s, the problems of technological innovation were an important issue to only a few traditionally science-based large companies, but it is now generally accepted that technological innovation is one of the most valued assets for firms. Major industrial companies now owe their origin and their continued existence to the successful application of technology in evolving new products and improved manufacturing process (Twiss 1980; Kumar and Siddharthan 1994). In the past, the Japanese firms got their technological innovation through the purchase of necessary technology overseas (Uno 1984). However, by the late 1970s, the most important management issue for Japanese CEOs was new product development (Nonaka 1980). In many industries, Japanese companies had reached the technological level of their foreign competitors and thus they were required to spend more of their own resources in acquiring new technological knowledge (Uno 1984; Ito and Pucik 1993). To remain competitive, Japanese firms had to emphasize on the importance of technical innovation at all levels in the manufacturing chain (Campbell 1985). In these aspects, as explained earlier, a relationship of some sort between research and development and firm's performance has been suggested, either explicitly or implicitly (Leonard 1971; Branch 1974; Gee 1981; Odagiri 1983; Rosenbloom and Cusumano 1987).

Like advertising and sales promotion, $R \& D$ expenditure is spent because it is expected to increase the firm's profitability. Especially, in contrast to the basic R\&D usually conducted by the U.S firms, Japanese firms are more interested in applied research that can directly lead to performance (Johnson 1984; Uno 1984). Report on the Survey of Research and Development (1993) indicated that Japanese manufacturing companies spent only $6.9 \%$ of their total $R \& D$ investment in basic research.

There are many ways in which firm's performance and R\&D may be related. Generally, it is believed that causality runs from $R \& D$ to sales, profits and productivity (Leonard 1971). However, it is possible that firm's performance may influence future R\&D spending or that both firm's performance and $R \& D$ influence each other and are inter-mixed. In this regard, Branch (1974), in his study of relationship between R\&D activity and profitability, found a tendency for $R \& D$ to influence future profitability but only slightly influenced by past profitability.

We therefore begin to formulate our hypothesis by considering the basic objective of almost all companies, that is to maximize profit. We hypothesize that companies budget their own money for $R \& D$ projects on the basis of the expected sales and profit of these projects. For the only justification for devoting scarce financial resources to 
research and development is the belief that they will generate innovations which will contribute to the company's survival and continued profitability. If the proposition that the profitability of the firm depends on $R \& D$ is correct, then we expect to observe that:

Hypothesis 1: Firm's amount of R\&D expenditure is positively associated with the firm's profitability.

Hypothesis 2: Firm's level of R\&D intensity is positively associated with the firm's profitability.

With respect to the firm size, there are hypotheses stating that in a mature capitalist economy, large firms generate disproportionately large shares of society's technological advances (Schumpeter 1950; Galbraith 1957). Schumpeter (1950) hypothesized that the large firm carries out $R \& D$ investment because the monopoly power it possesses enables it to take risks involved in R\&D. In this aspect, Scherer (1965) had found a positive relationship between $R \& D$ intensity and the firm size. He found that R\&D intensity increased with the firm size in chemical and petroleum industry. For other industries, R\&D increases with size up to the intermediate level and then decreased.

More recently, Cohen, Levin and Mowery (1987) reasoned that capital market imperfections confer an advantage on large firms in securing finance for risky R\&D projects, because size is correlated with the availability and stability of internallygenerated funds. There are also claims that a scale of economy is involved in the technology of R\&D. These claims reasoned that the returns from $R \& D$ are higher where the innovator has a large volume of sales to spread the fixed cost of R\&D. In addition, $R \& D$ is alleged to be more productive in large firms as a result of unity between $R \& D$ and other non-manufacturing activities that are usually better developed within large firms. In other words, larger firms should have a better R\&D management system and should therefore perform better than smaller ones in term of $R \& D$ efficiency.
Therefore, we expect to observe the Schumpeterian hypothesis that the level of $R \& D$ expenditures depends on the size of the firms and also propose that the firm's $R \& D$ efficiency is related to the size of the firm. Thus, we should observe that:

Hypothesis 3: Firm size is positively associated with the firm's R\&D efficiency.

Hypothesis 4: Firm size is positively associated with the firm's amount of R\&D spending.

Hypothesis 5: Firm size is positively associated with the firm's level of R\&D intensity.

\section{Data and Methodology}

\section{Source of Data}

The data on R\&D expenditures, profitability variables, the sales volume and assets of the firms are obtained from the Nikkei NEEDS database. This database contains comprehensive financial data of listed companies in Japanese Stock Exchanges. To make sure that the right variables are selected, we randomly pick some data from the Nikkei NEEDS database and cross-checked the selected variables with the data from Kaisha Zaimu Karute (1998) which contain similar data of the firms, but in less detail. The sample data of both database are almost identical with negligible differences which are believed to be caused by approximation. To control for industrial effects, only firms from the chemical and pharmaceutical $^{2)}$ are chosen. A total of 191 firms which match the category are obtained for the year 1992-1996. Since R\&D values will be used in all of our analyses, 21 firms are deleted because they do not report $R \& D$ values. This resulted in a total of 170 firms for our final sample. All other missing values are calculated on a case by case basis ${ }^{3}$.

Although the sample contains firms of all sizes, they are mostly large firms. The sample firms have average sales of about 107 billion yen and average total asset of about 141 billion yen in 199 $2^{4)}$. These results are not surprising since Japanese industrial $R \& D$ is mainly conducted by large firms which can recruit high quality research personnel (Miyata 1995). Table 1 reports the 
Firm Size and R\&D on Profitability. An Empirical Analysis on Japanese Chemical and Pharmaceutical Industry

Table 1: Descriptive Statistics of the Key Variables used. $(\mathrm{N}=170)$

\begin{tabular}{|c|c|c|c|c|c|}
\hline Variable & Mean & Std Dev & Min. & Max. & Label \\
\hline 1. $\log \left(R \& D_{92}\right)$ & 3.10 & .89 & .00 & 4.86 & Log-R\&D Cost in million yen (1992) \\
\hline 2. $\mathrm{R} \& \mathrm{D} \% 92$ & 4.40 & 4.12 & .01 & 17.94 & $\begin{array}{l}\text { R\&D Intensity } \%(1992) \\
(\mathrm{R} \& \mathrm{D} / \text { Sales }) \times 100\end{array}$ \\
\hline 3. $\log \left(\operatorname{asset}_{92}\right)$ & 4.82 & .54 & 3.78 & 6.07 & Log-Assets in Million Yen(1992) \\
\hline 4. $\mathrm{ROA}_{95}$ & 1.97 & 2.06 & -4.94 & 9.43 & $\begin{array}{l}\text { Return on Assets \%(1995) } \\
\text { (Current Income/Total Assets) } \times 100\end{array}$ \\
\hline 5. $\mathrm{ROE}_{95}$ & 2.62 & 22.13 & -279.25 & 17.36 & $\begin{array}{l}\text { Return on Equity \%(1995) } \\
\text { (Current Income/Stockholders' Equity) } \times 100\end{array}$ \\
\hline 6. $\mathrm{TAT}_{95}$ & .83 & .27 & .19 & 1.89 & $\begin{array}{l}\text { Total Asset Turnover(1995) } \\
\text { (Sales/Total Asset) }\end{array}$ \\
\hline 7. $\mathrm{GPM}_{95}$ & 32.44 & 17.35 & 12.45 & 81.98 & $\begin{array}{l}\text { Gross Profit Margin } \%(1995) \\
(\text { Gross Profit/Sales) } \times 100\end{array}$ \\
\hline 8. $\mathrm{OPM}_{95}$ & 6.02 & 4.84 & -2.59 & 34.02 & $\begin{array}{l}\text { Operating Income Margin } \%(1995) \\
\text { (Operating Income/Sales) } \times 100\end{array}$ \\
\hline 9. $\mathrm{ORM}_{95}$ & 5.89 & 5.86 & -4.80 & 37.77 & $\begin{array}{l}\text { Ordinary Income Margin } \%(1995) \\
\text { (Ordinary Income/Sales) } \times 100\end{array}$ \\
\hline
\end{tabular}

All variables are in percentages except for $\log \left(R \& \mathrm{D}_{92}\right), \log \left(\right.$ asset $\left._{92}\right)$ and $\mathrm{TAT}_{95}$

descriptive statistics and the calculation methods of the key variables used in this study.

The database has some shortcomings, though. Odagiri and Iwata (1986), while using NEEDS data in their analysis, did not deny the possibility that the firms may conduct R\&D but do not report them in their financial statements. They also pointed out that the R\&D coverage might be different from firm to firm, since there is no regulations in Japan as to which expenses should be included in the R\&D expenditure. However, Ito and Pucik (1993) claimed that although the early NEEDS data were unreliable in their R\&D coverage, the deficiency had been largely corrected by 1983, especially for the large corporations. Since most of the sample firms in our study are large corporations, NEEDS data represents the best available data at hand with large enough sample for reasonably accurate analyses.

\section{Methodology and Models}

Regression analysis is used in this study. The first question we investigate is the relationship between $R \& D$ and profitability. This regression model measures the elasticity of R\&D expenditure with respect to profitability, accounting for the effect of the firm size (Hypothesis 1). The equation is:

$$
\text { (1) } \begin{gathered}
\operatorname{profitability}_{95}=\alpha+\beta \log \left(\mathrm{R} \& \mathrm{D}_{92}\right) \\
+\gamma \log \left(\text { asset }_{92}\right)+\varepsilon
\end{gathered}
$$

where profitability ${ }_{95}$ consists of the 6 most widely used Japanese profitability variables namely, return on assets $\left(\mathrm{ROA}_{95}\right)$, return on equity $\left(\mathrm{ROE}_{95}\right)$, total asset turnover $\left(\mathrm{TOA}_{95}\right)$, gross profit margin $\left(\mathrm{GPM}_{95}\right)$, operating income margin $\left(\mathrm{OPM}_{95}\right)$, and ordinary income margin $\left(\mathrm{ORM}_{95}\right)$ for the year 1995. The $R \& D_{92}$ is the amount of $R \& D$ expenditure in 1992. This is expressed as the actual amount of R\&D spending in million yen as reported in the NEEDS database. Assets were used as a proxy for the firm size variable ${ }^{5)}$. Assets were chosen because they tend to fluctuate less over the business cycle. In this model, the variable (asset g $_{2}$ ) represents the assets of the firms in million yen for the year 1992, and is used to control for the possible effect of the firm size on profitability.

The second regression measures the elasticity of $R \& D$ intensity with respect to profitability, accounting for the effect of the firm size (Hypothesis 2 ). The same variables are used as the above Model (1), except that $\log \left(R \& D_{92}\right)$ is substituted by the R\&D intensity for the year $1992\left(\mathrm{R} \& \mathrm{D} \%{ }_{s 2}\right)$.

(2) profitability $_{95}=\alpha+\beta\left(\mathrm{R} \& \mathrm{D} \%{ }_{92}\right)$

$$
+\gamma \log \left(\text { asset }_{92}\right)+\varepsilon,
$$


$R \& D$ intensity is measured by the ratio of research expenditure to sales. By this measure, the absolute amount of R\&D expenditures are transformed into relative terms, enabling better comparisons to be made among companies. This approach proved to be the best and the most widely used measurement of a research effort (Leonard 1971).

Logarithmic transformations are used for the $R \& D$ expenditure and asset variables in the Model (1), and for the asset variable in the Model (2). Log values are used so that elasticity relationship between dependent and independent variables can be seen more clearly. In these models, the coefficient $\beta$ shows the elasticity of the $R \& D$ expenditure or R\&D intensity to profitability respectively. It represents the percentage change in profitability for a one percentage change in $\log \left(R \& D_{92}\right)$ or $\mathrm{R} \& \mathrm{D} \%$ s.

Time lags between R\&D and profitability are used in our study because the measurement of firm profitability may be rather sensitive to the time period being considered. Lag effects of the variables are necessary to control for differences in time-lag of R\&D and performance (Billings and Yaprak 1995). We follow the approaches employed by Ito and Pucik (1993) ${ }^{6)}$ in their study of the effect of $R \& D$, firm size and a competitive position on export performance, and also employed by Gomez-Mejia and Palich (1997) ${ }^{7)}$ in their study of cultural diversity and firm performance. In our study, we analyze the effect of R\&D on profitability, taking into account the effect of the firm size. Using their approach, our R\&D spending for the year 1992 is used to evaluate its effect on profitability for the year 1992 to 1996 . R\&D spending for 1992 is used as a base for calculation because it is the year in which the Japanese bubble economy collapsed. The regression equations were preliminarily run for five time periods: no time lag 1992 against 1992, one-year lag 1992 against 1993, twoyear lag 1992 against 1994, three-year lag 1992 against 1995 and four-year lag 1992 against 1996. For each of these lag periods, the effects of R\&D and the firm size in the year 1992 are tested for its impact on profitability for the respective year between 1992 and 1996. All five groups of regressions gave approximately the same results, with three-year lag having generally better $R^{2}$. Therefore, three-year lag (1992 R\&D against 1995 profitability) is used for discussions in this paper whenever R\&D is used as an independent variable. Summary of all 1992-1996 results is presented in Appendix 1.1 and 1.2 for reference.

For the Hypothesis 3 that the firm size is positively associated with the firm's R\&D efficiency, we sub-divided our sample into 2 groups: the smaller half and the larger half. Regressions were run on each of these two sub-groups respectively. Since the coefficient of $\log \left(R \& D_{92}\right)$ and $R \& D \% 92$ represents the percentage change in profitability measures for a one percentage change in the independent variables, it may be interpreted in this case as the efficiency of the firms in using $R \& D$ to generate profits. The higher the value of the coefficient, the more efficient the firms are in relation to the respective profitability variables. Using this definition, we compare the coefficient among firms of the two size-categories. If the coefficient of the larger firms is greater than that of smaller firms, larger firms can be said to be more efficient in $R \& D$ than smaller firms. On the other hand, if the coefficient of the smaller firms is greater than that of larger firms, smaller firms can be said to be more efficient in $R \& D$ than larger firms.

The next analysis we investigated was the relationship between R\&D and firm size (Hypothesis 4 and 5). This is straightforward. Simple regression equations are presented in the following forms:

$$
\begin{aligned}
& \text { (3) } \quad \begin{array}{l}
\log \left(\mathrm{R} \& \mathrm{D}_{92-96}\right)=\alpha+\beta \log \left(\text { asset }_{92-96}\right) \\
+\varepsilon, \text { and }
\end{array} \\
& \text { (4) } \quad \mathrm{R} \& \mathrm{D} \%_{92-96}=\alpha+\beta \log \left(\text { asset }_{92-96}\right)+\varepsilon
\end{aligned}
$$

Similar to the Model (1) and (2), logarithmic transformations are used for $R \& D$ expenditure and asset variables. In the Model (3) and (4), we analyze the impact of a firm size (asset) on the firm's R\&D expenditure and R\&D intensity for the respective year from 1992 to 1996 . 


\section{Results of the Analysis}

\section{$R \& D$ and Profitability}

We begin by regressing $\log \left(R \& D_{92}\right)$ on profitability measures, accounting for the effect of the firm size. As can be seen from Table 2, section (a), the results indicate a positive and significant relationship between the $\log \left(R \& D_{92}\right)$ and 4 profitability measures $\mathrm{ROA}_{95}, \mathrm{GPM}_{95}, \mathrm{OPM}_{95}$ and $\mathrm{ORM}$ 95. The exceptions are $\mathrm{ROE}_{95}$ which is positive but not significant, and $\mathrm{TAT}_{95}$ which is negative and not significant. Although some of the regressions failed to reach the significance level $\left(\mathrm{ROE}_{95}\right.$ and $\mathrm{TAT}_{95}$ ), the results give supporting evidence that $R \& D$ expenditure does have an impact on profit- ability. Hypothesis 1 that the firm's amount of $R \& D$ is positively associated with the firm's profitability is therefore supported. Similar results are obtained for $R \& D$ intensity $\left(R \& D \%_{92}\right)$ as can be seen from Table 2, section (b). With the exception of $\mathrm{TAT}_{95}$, all other profitability measures presented here are positively and significantly related to $R \& D \% \%_{92}$, indicating that an increase in $R \& D$ intensity leads to an increase in profitability. The variance is also more strongly explained in term of the size of adjusted $R^{2}$ than for the case of $\log \left(R \& D_{92}\right)$. Therefore, Hypothesis 2 that the firm's level of R\&D intensity is positively associated with the firm's profitability is also supported. In both section (a) and (b), most of

Table 2: Result of Regression Analysis: The Effect of R\&D and Size on Profitability. (Three-Year Lag for Profitability)

\begin{tabular}{|c|c|c|c|c|c|c|}
\hline$(\mathrm{N}=170)$ & Constant & $\log \left(R \& D_{92}\right)$ & $\mathrm{R \& D} \%_{92}$ & log (assett $\left.{ }_{92}\right)$ & Adjusted $\mathrm{R}^{2}$ & F-ratio \\
\hline \multicolumn{7}{|c|}{$\begin{array}{l}\text { Dependent Variables（Profitability Measures） } \\
\text { (a) }\end{array}$} \\
\hline $1 . \mathrm{ROA}_{95}$ & $\begin{array}{c}2.687 \\
(1.314)\end{array}$ & $\begin{array}{c}.734^{* *} \\
(2.094)\end{array}$ & & $\begin{array}{l}-.697 \\
(1.204)\end{array}$ & .017 & $2.475^{*}$ \\
\hline 2. $\mathrm{ROE}_{95}$ & $\begin{array}{c}3.984 \\
(.636)\end{array}$ & $\begin{array}{c}1.591 \\
(1.482)\end{array}$ & & $\begin{array}{r}-1.328 \\
(.749)\end{array}$ & .004 & 1.342 \\
\hline 3. $\mathrm{TAT}_{95}$ & $\begin{array}{l}1.328^{-} \\
(6.356)\end{array}$ & $\begin{array}{l}-.020 \\
(.571)\end{array}$ & & $\begin{array}{l}-.101^{*} \\
(1.715)\end{array}$ & .061 & $6.495^{--}$ \\
\hline 4.GPM 95 & $\begin{array}{l}52.568^{-*} \\
(4.032)\end{array}$ & $\begin{array}{l}13.673^{--} \\
(6.121)\end{array}$ & & $\begin{array}{c}-12.811^{*} \\
\quad(3.473)\end{array}$ & .194 & 21.301 \\
\hline $5 . \mathrm{OPM}_{95}$ & $\begin{array}{l}3.542 \\
(.746)\end{array}$ & $\begin{array}{l}1.948^{*} \\
(2.395)\end{array}$ & & $\begin{array}{l}-.752 \\
(.560)\end{array}$ & .048 & $5.287^{-}$ \\
\hline $6 . \mathrm{ORM}_{95}$ & $\begin{array}{l}2.308 \\
(.438)\end{array}$ & $\begin{array}{c}1.824^{-*} \\
(2.021)\end{array}$ & & $\begin{array}{l}-.522 \\
(.350)\end{array}$ & .036 & $4.157^{*}$ \\
\hline (b) & & & & & & \\
\hline $1 . \mathrm{ROA}_{95}$ & $\begin{array}{l}1.369 \\
(.810)\end{array}$ & & $\begin{array}{c}.169^{--} \\
(3.623)\end{array}$ & $\begin{array}{l}-.105 \\
(.294)\end{array}$ & .065 & $6.860^{-\cdots}$ \\
\hline $2 . \mathrm{ROE}_{95}$ & $\begin{array}{l}.586 \\
(.111)\end{array}$ & & $\begin{aligned} .279^{*} \\
(1.906)\end{aligned}$ & $\begin{array}{l}.146 \\
(.130)\end{array}$ & .012 & 2.063 \\
\hline $3 . \mathrm{TAT}_{95}$ & $\begin{array}{c}1.263^{-} \\
(7.567)\end{array}$ & & $\begin{array}{l}-.021 \\
(4.614)\end{array}$ & $\begin{array}{l}-.082^{*} \\
(2.305)\end{array}$ & .166 & $17.769^{--}$ \\
\hline 4.GPM 95 & $\begin{array}{l}28.689^{--} \\
(3.534)\end{array}$ & & $\begin{array}{c}3.268^{--} \\
(14.555)\end{array}$ & $\begin{array}{c}-2.043 \\
(1.186)\end{array}$ & .565 & $110.690^{--}$ \\
\hline $5 . \mathrm{OPM}_{95}$ & $\begin{array}{l}1.699 \\
(.477)\end{array}$ & & $\begin{array}{c}.721 \\
(7.316)\end{array}$ & $\begin{array}{c}.226 \\
(.299)\end{array}$ & .255 & $29.849^{--}$ \\
\hline $6 . \mathrm{ORM}_{95}$ & $\begin{array}{l}1.211 \\
(.306) \\
\end{array}$ & & $\begin{array}{c}.777^{-} \\
(7.097) \\
\end{array}$ & $\begin{array}{r}.169 \\
(.201) \\
\end{array}$ & .241 & $27.869^{--}$ \\
\hline
\end{tabular}

t-values are given in parentheses.

" $\mathrm{p}<.10 \quad \mathrm{p}<.05 \quad \mathrm{p} p<.01$ 
the coefficients for $\log$ (asset ( $_{92}$ ) are not statistically significant, indicating that the firm size does not have much effects on profitability.

\section{Firm Size and R\&D Efficiency}

Before proceeding with our next analysis, we would like to note again that the coefficient of $\log \left(R \& D_{92}\right)$ and $R \& D \%{ }_{92}$ may be explained as the efficiency of the firms in utilizing $R \& D$ expenditure to generate profit. Thus the higher the value of the coefficient, the more efficient those firms are in $R \& D$. To facilitate the comparison of the independent variables, standardized regression coefficient $^{8)}$ is used. The standardized regression coeffi- cient tells us that an increase of 1 standard deviations in the independent variable will result in an expected increase of $\beta$ standard deviations in the dependent variables. Table 3 presents the results of the R\&D efficiency of the 170 firms for 2 different size categories, the smaller half and the larger half.

According to the results, the magnitude of the beta coefficients of both $\log \left(R \& D_{92}\right)$ and $R \& D \%_{92}$ are positive and larger in larger half firms group and for all of the profitability variables, with the exception of $\mathrm{TAT}_{95}$ which is negative. However, the beta coefficient is not significant for smaller half firms in many of the analysis and the adjusted

Table 3: Result of Standardized Regression Analysis: The Effect of R\&D and Size on Profitability-Size Categories Sub-divided. (Three-Year Lag for Profitability)

\begin{tabular}{llllll}
\hline \hline$(\mathrm{N}=170)$ & $\log \left(\mathrm{R} \& \mathrm{D}_{92}\right)$ & $\mathrm{R} \& \mathrm{D} \% 92$ & $\log \left(\right.$ asset $\left._{92}\right)$ & Adjusted $\mathrm{R}^{2}$ & F-ratio \\
\hline
\end{tabular}

Dependent Variables (Profitability Measures)

1. $\mathrm{ROA}_{95}$ (Return on Assets)

(a) Smaller Half $(\mathrm{N}=85)$

Larger Half $(\mathrm{N}=85)$

All Firms $(N=170)$

(b) Smaller Half $(\mathrm{N}=85)$

Larger Half $(\mathrm{N}=85)$

All Firms $(\mathrm{N}=170)$

2. $\mathrm{ROE}_{95}$ (Return on Equity)

(a) Smaller Half $(\mathrm{N}=85)$ .089

( .731)

Larger Half $(\mathrm{N}=85)$

$.263^{*}$

(1.663)

.187

All Firms $(N=170)$

(1.482)

(b) Smaller Half $(\mathrm{N}=85)$

Larger Half $(\mathrm{N}=85)$

All Firms $(\mathrm{N}=170)$
(2.094)

$$
.009
$$

( . .073)

$-.300^{*}$

(1.953)

$-.151$

(1.204)

$$
.028
$$

.089
$(\quad 805)$

$.425^{-}$

(4.223)

$.281^{-}$

(3.623)

( .254)

$-.015$

( . .149)

$-.023$

( .294)

$-.018$

.264

.072

$4.283^{*}$

$2.475^{\circ}$

.393

$8.952-$

$6.860^{-}$

.065

$-.039$

$-.018$

.267

( . .318)

$-.133$

.013

1.532

( .838)

$-.094$

.004

1.342

(.749)

.084

$-.013$

$-.017$

.286

( . .756)

( . .117)

$.226^{-}$

.037

.031

$2.344^{\circ}$

(2.094)

( .344)

$.152^{*}$

.010

.012

2.063

$\mathrm{t}$-values are given in parentheses.

${ }^{*} \mathrm{p}<.10 \quad \mathrm{p}<.05 \quad \mathrm{p}<.01$ 
Firm Size and R\&D on Profitability. An Empirical Analysis on Japanese Chemical and Pharmaceutical Industry

Table 3: Result of Standardized Regression Analysis: The Effect of R\&D and Size on Profitability-Size Categories Sub-divided. (Three-Year Lag for Profitability)-Continued

$\begin{array}{llllll}(\mathrm{N}=170) & \log \left({\mathrm{R} \& \mathrm{D}_{92}}\right) & \mathrm{R} \& \mathrm{D} \% 92 & \log \left(\text { asset }_{92}\right) & \text { Adjusted } \mathrm{R}^{2} & \text { F-ratio }\end{array}$

Dependent Variables (Profitability Measures)

3. $\mathrm{TAT}_{95}$ (Total Assets Turnover)

\begin{tabular}{|c|c|c|c|c|c|}
\hline (a) Smaller Half $(\mathrm{N}=85)$ & \multicolumn{2}{|l|}{$\begin{array}{l}-.043 \\
(.350)\end{array}$} & $\begin{array}{l}-.040 \\
(.332)\end{array}$ & -.019 & .202 \\
\hline Larger Half $(\mathrm{N}=85)$ & $\begin{array}{l}-.056 \\
(.354)\end{array}$ & & $\begin{array}{l}-.113 \\
(.709)\end{array}$ & .001 & 1.059 \\
\hline All Firms $(N=170)$ & $\begin{array}{l}-.070 \\
(.571)\end{array}$ & & $\begin{array}{l}-.210^{*} \\
(1.715)\end{array}$ & .061 & $6.495^{--}$ \\
\hline (b) Smaller Half $(\mathrm{N}=85)$ & & $\begin{array}{l}-.375^{*} \\
(3.630)\end{array}$ & $\begin{array}{l}-.005 \\
(.044)\end{array}$ & .120 & $6.752=$ \\
\hline Larger Half $(\mathrm{N}=85)$ & & $\begin{array}{l}-.304^{-} \\
(2.914)\end{array}$ & $\begin{array}{l}-.124 \\
(1.191)\end{array}$ & .094 & $5.345^{-}$ \\
\hline All Firms $(\mathrm{N}=170)$ & & $\begin{array}{l}-.338^{-} \\
(4.614)\end{array}$ & $\begin{array}{l}-.169= \\
(2.305)\end{array}$ & .166 & $17.769=$ \\
\hline
\end{tabular}

4. GPM95 (Gross Profit Margin)

$396-$

(3.517)

Larger Half $(\mathrm{N}=85)$

$.810^{-}$

(6.042)

All Firms $(N=170)$

$.694^{-\cdots}$

(6.121)

(b) Smaller Half $(\mathrm{N}=85)$

Larger Half $(\mathrm{N}=85)$

All Firms $(N=170)$

5. $\mathrm{OPM}_{95}$ (Operating Income Margin)

(a) Smaller Half $(\mathrm{N}=85) \quad-.0 .21$

( .169)

Larger Half $(\mathrm{N}=85) \quad .545^{-}$

(3.643)

All Firms $(N=170)$

$.295^{\circ}$

(2.395)

(b) Smaller Half $(\mathrm{N}=85)$

Larger Half $(\mathrm{N}=85)$

All Firms $(N=170)$
$-.041$

(.362)

$-.617-$

(4.604)

$-.394$

(3.473)

$.698^{--}$

(8.793)

$.786^{-}$

(11.384)

$.770^{--}$

(14.555)

.027

( . .341)

$-.103$

(1.497)

$-.063$

(1.186)
.124

.292

.194

.481

.603

$6.962^{-}$

$18.296^{-}$

$21.301 *$

$39.974^{-}$

$64.874^{-}$

.565

$110.690^{--}$

$-.082$

$-.016$

( .675)

$-.411^{--}$

.118

(2.750)

$-.069$

.048

$-.135$

(1.274)

(2.908)

$-.072$

( .807)

(6.659)

.021

$.507^{-*}$

(7.316)
.079

.335

.354

$6.645^{-}$

$5.287^{-}$

$4.603^{-}$

$22.181^{-}$

.255

$29.849^{-}$

t-values are given in parentheses.

${ }^{*} \mathrm{p}<.10 \quad \mathrm{p}<\mathrm{p}<\mathrm{p} \quad \mathrm{p}<.01$ 
Table 3: Result of Standardized Regression Analysis: The Effect of R\&D and Size on Profitability-Size Categories Sub-divided. (Three-Year Lag for Profitability)-Continued

\begin{tabular}{|c|c|c|c|c|c|}
\hline$(\mathrm{N}=170)$ & $\log \left(\mathrm{R} \& \mathrm{D}_{92}\right)$ & $\mathrm{R} \& \mathrm{D} \%_{92}$ & $\log \left(\right.$ asset $\left._{92}\right)$ & Adjusted $\mathrm{R}^{2}$ & F-ratio \\
\hline \multicolumn{6}{|c|}{ Dependent Variables (Profitability Measures) } \\
\hline \multicolumn{6}{|c|}{ 6. $\mathrm{ORM}_{95}$ (Ordinary Income Margin) } \\
\hline \multirow[t]{2}{*}{ (a) Smaller Half $(\mathrm{N}=85)$} & -.079 & & .030 & -.019 & .211 \\
\hline & (.649) & & $(.248)$ & & \\
\hline \multirow[t]{2}{*}{ Larger Half $(\mathrm{N}=85)$} & .540 & & $-.398 *$ & .116 & $6.493^{*-*}$ \\
\hline & (3.603) & & $(2.656)$ & & \\
\hline \multirow[t]{2}{*}{ All Firms $(N=170)$} & $.251^{* *}$ & & -.043 & .036 & $4.157^{* *}$ \\
\hline & $(2.021)$ & & $(.350)$ & & \\
\hline \multirow[t]{2}{*}{ (b) Smaller Half $(\mathrm{N}=85)$} & & $.308^{-*}$ & -.048 & .071 & $4.208^{*}$ \\
\hline & & $(2.901)$ & $(.449)$ & & \\
\hline \multirow[t]{2}{*}{ Larger Half $(\mathrm{N}=85)$} & & $.578^{-*}$ & -.061 & .314 & $20.244^{* *}$ \\
\hline & & (6.363) & ( .669) & & \\
\hline \multirow[t]{2}{*}{ All Firms $(N=170)$} & & $.496 *$ & .014 & .241 & $27.869^{-}$ \\
\hline & & $(7.097)$ & (.201) & & \\
\hline
\end{tabular}

t-values are given in parentheses.

${ }^{*} \mathrm{p}<.10 \quad \mathrm{p}<.05 \quad-\mathrm{p}<.01$

$\mathrm{R}^{2}$ is negative ${ }^{9)}$ in many instances, indicating that R\&D does not have an impact on most profitability measures for smaller firms. For example, the beta coefficient of $\log \left(R \& D_{92}\right)$ for smaller half firms is significant only for $\mathrm{GPM}_{95}$, and the beta coefficient of $R \& D \%{ }_{92}$ for smaller half firms is positive and significant only for $\mathrm{GPM}_{95}, \mathrm{OPM}_{95}$ and $\mathrm{ORM}_{95}$. Nevertheless, the beta coefficients for larger firms are larger than the beta coefficients for all firms in all analyses. For example, the beta coefficient of $\log \left(R \& D_{92}\right)$ is .396 for $\mathrm{GPM}_{95}$ in smaller half firms, but it is .810 in larger half firms, compared with .694 for all firms. Similarly, the beta coefficient of $\mathrm{R} \& \mathrm{D} \%{ }_{92}$ for $\mathrm{OPM}_{95}$ is .308 in smaller half firms, but it is .595 in larger half firms, compared with .507 for all firms. Taken together, the implication of these findings is that the R\&D funds in larger firms are used more efficiently to generate profits. Though the results are not consistent for all profitability measures, the findings do provide some evidence that larger firms are more efficient in term of R\&D efficiency and thus Hypothesis 3 is partly supported.

\section{$R \& D$ expenditure and firm size}

Table 4 reports the results of our analysis related to the effect of firm size on $\log \left(R \& D_{92-96}\right)$ and on $\mathrm{R} \& \mathrm{D} \%_{92-96}$. According to the results, we found that the size of the firm effects both $R \& D$ spending and R\&D intensity. All of the size coefficients from the year 1992 to 1996 showed the expected positive sign and are statistically significant at $\mathrm{p}<.01$. The empirical findings strongly correspond to the Hypotheses (4) and (5) that the firm size is positively associated with the amount of R\&D spending and the level of R\&D intensity. Our Hypotheses (4) and (5) are therefore supported.

\section{Discussion and Conclusion}

The purposes of this study are to investigate the effect of $R \& D$ expenditure and $R \& D$ intensity on profitability and to examine the differences in efficiency of the R\&D expenditure and R\&D intensity among firms of different sizes. In addition, the effect of the firm size on R\&D is also studied. In these aspects, we have found positive relationship between R\&D and profitability. We have also found that larger Japanese chemical and pharmaceutical firms are more efficient in their management of R\&D spending for profit when compared 
Firm Size and R\&D on Profitability. An Empirical Analysis on Japanese Chemical and Pharmaceutical Industry

Table 4: Result of Regression Analysis: The Effect of Firm Size on R\&D (1992-1996).

\begin{tabular}{|c|c|c|c|c|}
\hline & $\overline{\text { Constant }}$ & $\overline{\log \left(\text { asset }_{92.96}\right)}$ & Adjusted $\mathrm{R}^{2}$ & $\overline{\text { F-ratio }}$ \\
\hline \multicolumn{5}{|c|}{ Dependent Variables } \\
\hline \multicolumn{5}{|l|}{$\log (R \& D)$} \\
\hline \multirow[t]{2}{*}{$1992(\mathrm{~N}=170)$} & $-3.208^{* *}$ & $1.309 \cdots$ & .627 & $284.794^{-\cdots}$ \\
\hline & $(8.531)$ & (16.876) & & \\
\hline \multirow[t]{2}{*}{$1993(\mathrm{~N}=170)$} & -3.149 & $1.301^{-}$ & .638 & $299.252^{*}$ \\
\hline & $(8.638)$ & (17.299) & & \\
\hline \multirow[t]{2}{*}{$1994(\mathrm{~N}=169)$} & -3.130 & $1.299 *$ & .687 & $369.363^{*}$ \\
\hline & (9.544) & (19.219) & & \\
\hline \multirow[t]{2}{*}{$1995(\mathrm{~N}=168)$} & $-3.044=$ & $1.278^{-}$ & .675 & $347.866^{-*}$ \\
\hline & $(9.139)$ & (18.651) & & \\
\hline \multirow[t]{2}{*}{$1996(\mathrm{~N}=169)$} & $-3.313^{-}$ & $1.329^{-}$ & .663 & $331.730^{-}$ \\
\hline & (9.331) & (18.213) & & \\
\hline \multicolumn{5}{|l|}{$\mathrm{R} \& \mathrm{D} \%$} \\
\hline \multirow[t]{2}{*}{$1992 （ \mathrm{~N}=170)$} & $-6.117^{*}$ & $2.184=$ & .076 & $14.826^{* *}$ \\
\hline & $(2.225)$ & $(3.850)$ & & \\
\hline \multirow[t]{2}{*}{$1993(\mathrm{~N}=170)$} & $-6.376^{*}$ & $2.276^{-}$ & .084 & 16.482 \\
\hline & $(2.347)$ & $(4.060)$ & & \\
\hline \multirow[t]{2}{*}{$1994(\mathrm{~N}=169)$} & $-6.399^{*}$ & $2.294-$ & .081 & $15.769^{-}$ \\
\hline & $(2.283)$ & ( 3.971$)$ & & \\
\hline \multirow[t]{2}{*}{$1995(\mathrm{~N}=168)$} & $-6.695^{*}$ & $2.339^{-}$ & .083 & $16.136^{--}$ \\
\hline & $(2.364)$ & ( 4.017$)$ & & \\
\hline \multirow[t]{2}{*}{$1996(\mathrm{~N}=169)$} & $-6.865^{*}$ & $2.373^{-}$ & .080 & $15.550^{--}$ \\
\hline & $(2.344)$ & ( 3.943$)$ & & \\
\hline
\end{tabular}

$\mathrm{t}$-values are given in parentheses.

" $\mathrm{p}<.10 \quad \mathrm{p}<.05 \quad \mathrm{p} p<.01$

with smaller firms. In addition, we have found significant relationship between $R \& D$ and a firm size, implying that larger firms spend more on $R \& D$ and are more $R \& D$ intensive than smaller firms. In summary, larger firms spend more on $R \& D$ and are more efficient in turning their $R \& D$ into profit, giving the fact that $R \& D$ does have an effect on profitability of the firm.

Caution should be taken in interpreting the results, however. It must be noted that the firm's profitability does not directly depend on $R \& D$ expenditure or $R \& D$ intensity alone but moderated by the firm's strategies. Our task would be easier if we conclude that an increase in $R \& D$ will lead to an increase in profit. Unfortunately, this is not so. An increase in R\&D spending or intensity will only be counter-productive to the firm unless the management possesses the ability to transform the technological creativity into profitable business operation. Firm can not just increase its' $R \& D$ expenditure or $R \& D$ intensity and then expect its profitability to improve. Other factors must be taken into considerations. The amount of the firm R\&D depends on the firm's policy adopted and implemented. For example, it is important that the firm has sufficient marketing power to turn $R \& D$ research outputs into profitable operations. Managers, when allocating the R\&D budget, must make a long term planning and forecast the amount of $R \& D$ that best suit their firm's ability and conditions. Seen in this perspective, Twiss (1980) argued that the challenge for corporate managers is not one of innovation but of managing technological innovation for profit. He stressed the importance of the whole innovation process leading to commercial exploitation. Therefore, in interpreting the result, it is important to consider also other fundamental 
factors that jointly explain performance: like the structure of demand, the different in technological advantages and the overall economics.

What we can say here is that as far as our sample is concerned, larger firms do invest more both in terms of $R \& D$ expenditure and $R \& D$ ratio to sales, and that these increases in $R \& D$ do have some relation with the profit. This finding seems to indicate that research and development for chemical and pharmaceutical firms in Japan has been rather efficient in the sense that the amount of $R \& D$ expenditure and $R \& D$ ratio are related to the profitability, especially for those of larger firms. A reason may be that resources devoted to $R \& D$ can be justified only if they can attain the corporate objectives. When a firm increases its $R \& D$ spending, it will expect that to result in profit. If the R\&D investment does not perform as well as it costs, that firm will reduce its $R \& D$ investment until cost-performance matches. Finally, all firms in the industry will reach an equilibrium at the point where additional R\&D spending will not lead to an increase in profitability of the firms. In this aspect, the results found here justify the cause for firms in the sample to devote limited resources to research and development.

This study may have some shortcomings. Firstly, the multi-product character of large firms has been ignored. The sample firms are selected based on their primary business, in this case, the chemical and pharmaceutical, whereas they may also involve in other businesses with different condition and market. However, we belief this is not a critical problem since Japanese firms tends to diversify less when compared to Western firms (Ito and Pucik 1993). Secondly, R\&D values in the database may not reflect all the R\&D efforts of the firms. Other $R \& D$ related variables which may be included in the study are the number of patents owned and number of $R \& D$ researchers. However, Leonard (1971) argued that as a measure of technical output, industrial R\&D has advantages over patents, because $R \& D$ includes research and development efforts while patents are representative of only development. He argued that although R\&D expenditures are treated in accounting as an operating expenses, they can be regarded as an investment decision made by management after comparing the likely profitability of research programs with alternative uses of the firm's funds. Thirdly, the effect of R\&D may be cumulative. The profitability may not reflect the result of R\&D of any particular year, but a continuous effort of long term research and development conducted by the firms over years. Lastly, as explained earlier, we have found a causal link between $R \& D$ and profitability and also relationship between the firm size and R\&D. However, we assume that R\&D leads to profitability, not the other way around. Though this is the approach used by most researchers studying $R \& D$ and firm performance, the reverse may be true ${ }^{10)}$. Profitability may lead to an increase in R\&D which in turn increases the firm's profitability, or it may be that the firm becomes larger because of the success in R\&D program. Seen in these prospects, research aiming at investing the cumulative effect of $R \& D$ or interactive effects of profitability on future $R \& D$ might be an interesting topic for the future study.

\section{Notes:}

1) The R\&D ratio to sales of Japanese chemical industry (pharmaceutical included) was $5.15 \%$ in 1996 , having third highest $R \& D$ intensity following software (9.83\%) and electronic (5.81\%) industries, compared to the average of $2.77 \%$ for all industries. In term of absolute amount, it covered $15.8 \%$ of total corporate R\&D spending in Japan in 1996. (Source: Report on the Survey of Research and Development 1997)

2) We follow the industrial classification employed by the Tokyo Stock Exchange.

3 ) Firms that do not report a variable that is needed for a particular analysis are excluded temporarily from that particular analysis. For other analysis, they are included as the sample as normal.

4) Excluding 10 outliner firms with largest sales volume and asset resulted in the average sales dropping to about 76 billion yen and average 
Firm Size and R\&D on Profitability. An Empirical Analysis on Japanese Chemical and Pharmaceutical Industry

total assets dropping to about 101 billion yen. We tested-run a few regressions on this excluded sample but the results of the analysis remained similar to the ones shown in Table 1 to 4.

5 ) Preliminarily, a few regression were also run using other size variables such as sales volume and number of employees, but the results are very similar.

6) In his paper, he examined three factors influencing the export performances of Japanese manufacturing firms, namely $R \& D$ spending, domestic competitive position, and firm size. In order to analyze the time lag between the effect of $R \& D$ and export performance, he used the R\&D data of the base year 1983 as the independent variable and repeated the regression using export performance data for 1983, 1984, 1985 and 1986 as the dependent variables.

7 ) In attempt to study the relationship between cultural diversity and firm performance, Gomez-Mejia and Palich (1997) ran regression equation for three periods 1985-1989, 1990-1994, and 1985-1994, using average performance measure as the dependent variable. Recognizing that performance averages may mask longitudinal effects, they also conducted a secondary regression analysis for each singular year during 1985-1994 with firm performance for each year as the dependent variable. For this annual analysis, the 1985 cultural indices were used to predict performance during 1985-1990, and the 1990 cultural indices were used to predict performance during 1990-1994.

8) Standardized regression coefficients are the regression coefficients when all variables are expressed in standardized (z-score) form. Transforming the independent variables to standardized form makes the coefficients more comparable since they are all in the same units of measure.

9) The adjusted R2 can be negative. See Maddala 1992, page 166 for detailed explanation.

10) See Branch (1974) for a more detail study on comparison of the impact of profitability on future R\&D.

\section{References}

Billings, Anthony B. and Yaprak, Attila. 1995. "Inventive Efficiency: How the U.S. Compares with Japan." R\&D Management, Vol.25, No.4. Oct. pp.365-376.

Branch, Ben. 1974. "Research and Development Activity and Profitability: A Distributed Lag Analysis." Journal of Political Economy, Vol.82, No.5. Sep/Oct. pp.999-1011.

Campbell, N. 1985. "Sources of Competitive Rivalry in Japan.” Journal of Productive Innovation Management, December. pp.224-231.

Cohen, Wesley M., Levin, Richard C. and Mowery, David C. 1987. "Firm Size and R\&D Intensity: A Re-Examination." The Journal of Industrial Economics, Vol.35, No. 4. June. pp.543565.

Franko, L.G. 1989. “Global Corporate Competition: Who's winning, Who's Losing, and the R\&D Factor as one Reason Why." Strategic Management Journal, Vol.10. pp.449-474.

Galbraith, J.K. 1957. "American Capitalism: The Concept of Countervailing Power." M. E. Sharpe, White Plains, N.Y.

Gee, Sherman. 1981. "Technological Transfer, Innovation, and International Competitiveness." John Wiley \& Sons, Inc.

Gomez-Mejia, R. Luis and Palich, E. Leslie. 1997. "Cultural Diversity and the Performance of Multinational Firms." Journal of International Business Studies, Vol.28. No.2. Second Quarter. pp.309-335.

Gruber, William H., Mehta, Dileep amd Vernon, Raymond. 1967. "The R\&D Factor in International Trade and Investment of U.S. Industries." Journal of Political Economy, Vol. 75. pp.20-37.

Ito, Kiyohiko and Pucik, Vladimir. 1993. “R\&D Spending, Domestic Competition, and Export Performance of Japanese Manufacturing Firms." Strategic Management Journal, Vol.14. No.1. Jan. pp.61-75. 
Johnson, S.B. 1984. "Comparing R\&D Strategies of Japanese and U.S. Firms." Sloan Management Review, Vol.25. pp.25-34.

Kaisha Zaimu Karute 1998. Toyo Keisaishinpousha. Toyokeizai Data Bank '98.

Kumar, Nagesh and Siddharthan, N.S. 1994. "Technology, Firm Size and Export Behavior in Developing Countries: The Case of Indian Enterprise." The Journal of Development Studies, Vol.31, No.2, December. pp.289-309.

Leonard, William N. 1971. "Research and Development in Industrial Growth." Journal of Political Economy, Vol.79, No. 2, March/ April. pp.232-256.

Levin, Richard C. and Reiss, Peter C. 1981. "Tests of a Schumpeterian Model of R\&D and Market Structure”. In Griliches Zvi (ed.). R\&D, Patents and Productivity. The University of Chicago Press, Chicago. pp.175-208.

Maddala, G.S. 1992. "Introduction to Econometrics" Prentice Hall International Editions.

Miyata, Yukio. 1995. "An Economic Analysis of Cooperative R\&D in Japan." Japan and the World Economy Vol.7, No.3. pp.329-345.

Namiki, Nobuaki. 1996. "Kenkyuu Kaihatsuhi to Yushutsu no Kankei: Nihonkigyou to Beikokukigyou no Hikakutekikenkyuu (Relationship between R\&D Cost and Export: A Comparative Study of Japanese and U.S Firms.)" Nihon Boueki Gakkai, Nihon Gakkai Nenpou, Vol. 33, pp.119-121.

Nonaka, I. 1980. Keiei Kanri (Business Management), Nippon Keizai Shinbunsha, Tokyo.

Nikkei NEEDS database. 1997. Nihon Keizai Shimbunsha.

Odagiri, Hiroyuki. 1983. "R\&D Expenditures. Royalty Payments and Sales Growth in
Japanese Manufacturing Corporations." Journal of Industrial Economics, Vol.32, No.1, September. pp.61-71.

Odagiri, Hiroyuki and Iwata, Hitoshi. 1986. "The Impact of $R \& D$ on Productivity Increase in Japanese Manufacturing Companies." Research Policy Vol. 15, No.1. February. pp.1319.

Report on the Survey of Research and Development 1997. Kagaku Gijutsu Kenkyu Chosa Houkoku. Statistics Bureau, Management and Coordination Agency of the Government of Japan.

Rosenbloom, R.S. and Cusumano, M.A. 1987. "Technological Pioneering and Competitive Advantage: The Birth of the VCR Industry." California Management Review, Vol.29, No.4. Summer, pp.51-76.

Scherer, F.M. 1965. "Size of Firm, Oligopoly, and Research: A comment." Canadian Journal of Economics, Vol.31, No.2. pp.256-66.

Schumpeter, J.A. 1950. "Capitalism, Socialism, and Democracy." Harper \&Row, New York.

Twiss, Brian Charles. 1980. "Managing Technological Innovation.” 2nd Edition. Longman Group Limited.

Uno, Kimio. 1984. "Recent Trends in R\&D and Patents-A Quantitative Appraisal." In Eto Hajime and Matsui Konomu (eds.), R\&D Management Systems in Japanese Industry. Elsevier Science Publisher B.V. pp. 113-137.

Watanabe, Chihiro. 1995. "The Feedback Loop between Technology and Economic Development: An Examination of Japanese Industry." Technological Forecasting and Social Change, Vol.49, No.2. pp.127-145. （平成11年 9 月 29 日受稿，平成11年10月 30 日受理） 
Firm Size and R\&D on Profitability. An Empirical Analysis on Japanese Chemical and Pharmaceutical Industry

Appendix 1.1: Summary of Regression Results of the Effect of 1992 R\&D Expenditure and Size on Profitability (1992-1996)

\begin{tabular}{|c|c|c|c|c|c|}
\hline$(\mathrm{N}=170)$ & Constant & $\log \left(R \& D_{92}\right)$ & $\overline{l o g}\left(\right.$ asset $\left._{22}\right)$ & Adjusted $\mathrm{R}^{2}$ & F-ratio \\
\hline \multicolumn{6}{|c|}{ Dependent Variables (Profitability Measures) } \\
\hline \multicolumn{6}{|l|}{ ROA } \\
\hline 1992 & 2.423 & $.782^{-}$ & -.597 & .043 & $4.806^{--}$ \\
\hline 1993 & 2.323 & $.753^{*}$ & -.663 & .025 & $3.138^{*}$ \\
\hline 1994 & 1.622 & .577 & -.437 & .008 & 1.643 \\
\hline 1995 & 2.687 & $.734^{* *}$ & -.697 & .017 & $2.475^{*}$ \\
\hline 1996 & -.476 & .226 & .268 & -.006 & .504 \\
\hline \multicolumn{6}{|l|}{ ROE } \\
\hline 1992 & 2.667 & 3.623 & -2.341 & -.001 & .948 \\
\hline 1993 & 5.721 & 1.144 & -1.345 & .002 & 1.178 \\
\hline 1994 & 2.516 & .784 & -.564 & -.010 & .191 \\
\hline 1995 & 3.984 & 1.591 & -1.328 & .004 & 1.342 \\
\hline 1996 & -4.808 & -1.547 & 2.782 & -.008 & .301 \\
\hline \multicolumn{6}{|l|}{ TAT } \\
\hline 1992 & $1.521^{-}$ & .009 & $-.149^{*}$ & .063 & $6.700^{-}$ \\
\hline 1993 & $1.431=$ & .002 & $-.131^{*}$ & .057 & $6.117^{-*}$ \\
\hline 1994 & $1.274^{*}$ & -.015 & -.092 & .049 & $5.328^{-}$ \\
\hline 1995 & $1.328^{-}$ & -.020 & $-.101^{*}$ & .061 & $6.495^{*}$ \\
\hline 1996 & $1.120^{-}$ & -.040 & -.047 & .042 & $4.744^{-}$ \\
\hline \multicolumn{6}{|l|}{ GPM } \\
\hline 1992 & $51.927^{-}$ & $13.692^{-}$ & $-12.855^{-}$ & .197 & $21.710^{*}$ \\
\hline 1993 & $49.685^{-}$ & $13.558^{--}$ & $-12.317^{-}$ & .189 & $20.678^{-}$ \\
\hline 1994 & $52.166^{-}$ & $13.690^{-}$ & -12.864 & .191 & 20.951 \\
\hline 1995 & $52.568^{-}$ & $13.673^{-}$ & -12.811 & .194 & 21.301 \\
\hline 1996 & $52.157^{-}$ & 14.114 & -12.967 & .214 & $24.036^{-}$ \\
\hline \multicolumn{6}{|l|}{ OPM } \\
\hline 1992 & 4.225 & 1.033 & -.291 & .015 & $2.329^{*}$ \\
\hline 1993 & 1.149 & 1.333 & .007 & .030 & $3.583^{* *}$ \\
\hline 1994 & 3.513 & $1.662^{*}$ & -.748 & .028 & $3.407^{*}$ \\
\hline 1995 & 3.542 & $1.948^{*}$ & -.752 & .048 & $5.286^{*}$ \\
\hline 1996 & .694 & $1.891^{*}$ & -.102 & .063 & $6.729^{-*}$ \\
\hline \multicolumn{6}{|l|}{ ORM } \\
\hline 1992 & 2.810 & $1.909^{*}$ & -.588 & .050 & $5.481^{-}$ \\
\hline 1993 & -1.059 & 1.472 & .316 & .037 & $4.205^{*}$ \\
\hline 1994 & 2.108 & $1.710^{*}$ & -.574 & .024 & $3.109^{*}$ \\
\hline 1995 & 2.308 & $1.824^{*}$ & -.522 & .036 & $4.157^{*}$ \\
\hline 1996 & .376 & $1.566^{*}$ & .121 & .036 & $4.119^{*}$ \\
\hline
\end{tabular}


Appendix 1.2: Summary of Regression Results of the Effect of 1992 R\&D Intensity and Size on Profitability(1992-1996)

\begin{tabular}{|c|c|c|c|c|c|}
\hline$(\mathrm{N}=170)$ & Constant & R\&D\% ${ }_{92}$ & $\overline{l o g}\left(\right.$ asset $\left._{22}\right)$ & Adjusted $\mathrm{R}^{2}$ & F-ratio \\
\hline \multicolumn{6}{|c|}{ Dependent Variables (Profitability Measures) } \\
\hline \multicolumn{6}{|l|}{$\mathrm{ROA}$} \\
\hline 1992 & .858 & $.155^{-*}$ & .090 & .089 & $9.280^{-*}$ \\
\hline 1993 & 1.088 & $.193^{* * *}$ & -.098 & .103 & $10.653^{-}$ \\
\hline 1994 & 1.001 & $.201 *$ & -.121 & .090 & $9.354^{-}$ \\
\hline 1995 & 1.369 & $.169^{-}$ & -.105 & .065 & $6.860^{-}$ \\
\hline 1996 & -1.062 & .023 & .514 & -.006 & .472 \\
\hline \multicolumn{6}{|l|}{$\mathrm{ROE}$} \\
\hline 1992 & -6.083 & .470 & 1.377 & -.001 & .880 \\
\hline 1993 & 3.503 & $.237^{*}$ & -.365 & .020 & $2.734^{*}$ \\
\hline 1994 & 1.880 & .308 & -.209 & .003 & 1.232 \\
\hline 1995 & .586 & $.279^{*}$ & .146 & .012 & 2.063 \\
\hline 1996 & -2.257 & -.395 & 1.617 & -.001 & .909 \\
\hline \multicolumn{6}{|l|}{ TAT } \\
\hline 1992 & $1.348^{--}$ & $-.023^{-}$ & $-.086^{*}$ & .180 & 19.492 \\
\hline 1993 & $1.301^{-}$ & $-.020^{-}$ & $-.084^{*}$ & .151 & $16.032^{--}$ \\
\hline 1994 & $1.203^{-}$ & $-.020^{-}$ & $-.070^{-}$ & .146 & $15.400^{--}$ \\
\hline 1995 & $1.263^{-}$ & $-.021-$ & $-.082^{-}$ & .166 & $17.769^{--}$ \\
\hline 1996 & $1.103^{-}$ & $-.024^{-}$ & -.047 & .179 & $19.425^{--}$ \\
\hline \multicolumn{6}{|l|}{ GPM } \\
\hline 1992 & $28.074=$ & $3.282^{-}$ & -2.093 & .577 & $116.469^{-*}$ \\
\hline 1993 & $26.356^{--}$ & $3.297^{-}$ & -1.764 & .563 & $109.993^{-}$ \\
\hline 1994 & $28.402-$ & $3.296^{-}$ & -2.135 & .566 & $111.119^{-}$ \\
\hline 1995 & $28.689^{-*}$ & $3.268^{--}$ & -2.043 & .565 & $110.690^{--}$ \\
\hline 1996 & $26.795^{-}$ & $3.257^{-}$ & -1.597 & .577 & $116.126^{-}$ \\
\hline \multicolumn{6}{|l|}{ OPM } \\
\hline 1992 & 4.034 & $.510^{-}$ & -.054 & .177 & $19.231^{-}$ \\
\hline 1993 & .933 & $.664^{-}$ & .303 & .218 & $24.561^{--}$ \\
\hline 1994 & 2.323 & $.677^{* *}$ & -.051 & .208 & $23.218^{--}$ \\
\hline 1995 & 1.699 & .721 & .226 & .255 & $29.849^{--}$ \\
\hline 1996 & -1.494 & $.634^{-*}$ & .990 & .211 & $23.621^{-}$ \\
\hline \multicolumn{6}{|l|}{ ORM } \\
\hline 1992 & .933 & $.694^{*}$ & .396 & .240 & $27.730^{--}$ \\
\hline 1993 & -1.038 & $.775^{-}$ & .551 & .240 & $27.669^{--}$ \\
\hline 1994 & 1.355 & $.774^{-\infty}$ & -.025 & .211 & $23.566^{--}$ \\
\hline 1995 & 1.211 & $.777^{-}$ & .169 & .241 & $27.869^{--}$ \\
\hline 1996 & -.388 & $.696^{-}$ & .651 & .192 & $21.139^{--}$ \\
\hline
\end{tabular}

